\title{
Pengaruh Jus Tomat Terhadap Penurunan Tekanan Darah Lansia Dengan Hipertensi
}

\author{
${ }^{1}$ Hapipah*, ${ }^{2}$ Maelina Ariyanti, ${ }^{3}$ Ulfatul Izzah, ${ }^{4}$ Istianah \\ STIKES YARSI Mataram. \\ *email: hapipah.mataram15@yahoo.co.id
}

\begin{abstract}
Kata Kunci :
Abstrak

Hipertensi; Jus

Peningkatan usia dapat menyebabkan penurunan permeabilitas pembuluh darah sehingga memicu Tomat; Lansia terjadinya hipertensi. Penatalaksanaan hipertensi dapat dilakukan dengan tekhnik farmakologi dan non farmakologi. Salah satu tekhnik nonfarmakologi untuk menurunkan tekanan darah pada lansia dengan mengkonsumsi buah tomat. Kandungan dalam buah tomat adalah lycopene, bioflavonoid dan kalium yang diketahui sebagai antioksidan yang baik bagi penderita hipertensi. Tujuan penelitian adalah mengetahui pengaruh pemberian jus tomat terhadap penurunan tekanan darah pada lansia dengan

Key Words: hipertensi. Desain penelitian yang digunakan adalah Pre-Eksperimen dengan pendekatan One Group Hypertension; Tomato Pre - Post Test without control Design dan pengambilan data dilakukan dengan cara purposive sampling dengan jumlah responden 16 orang. Penelitian ini dilakukan selama 7 hari dan responden Juice;Elderly diukur tekanan darahnya 10 menit sebelum konsumsi jus tomat, dan 30 menit setelah konsumsi jus tomat. Hasil uji analisa Wilcoxon menunjukkan penurunan tekanan darah dengan nilai $p=0,000$ ( $\mathrm{p}<0$, 05), artinya hasil analisis menunjukkan bahwa adanya penurunan tekanan darah sistole dan diastole sesudah pemberian jus tomat. Berdasarkan hasil penelitian ini dapat disimpulkan bahwa dengan mengonsumsi jus tomat rutin setiap hari dapat menurunkan tekanan darah secara signifikan pada penderita hipertensi.
\end{abstract}

Info Artikel:

Tanggal dikirim: 20 Februari 2019

Tanggal direvisi:

24 April 2019

Tanggal diterima:

9 Mei 2019

DOI Artikel:

$10.33862 /$ citrad

elima.v3i1.44

Halaman: 5 - 9

\section{Abstract}

Increased age can cause a decrease in blood vessel permeability which can lead to hypertension. Management of hypertension can be done with pharmacology and non-pharmacological techniques. One nonpharmacology technique to reduce blood pressure in the elderly by consuming tomatoes. The content in tomatoes is lycopene, bioflavonoids and potassium which are known to be good antioxidants for people with hypertension. The aim of thisresearch is to know the effectiveness of tomato juice toward the decrease of blood pressure in elderly with hypertension. The research design used in this research is pre-experiment design with one group pre-post test and data collection conducted using purposive sampling with 16 respondents. This research conducted for 7 days and the respondent measured his blood pressure 10 minutes before tomato juice consumption, and 30 minutes after consumption of tomato juice. The result of the analysis of Wilcoxon of blood pressure decrease with statistically significant result $p=0.000(\mathrm{p}<0,05)$, meaning that the result of analysis showed that the decrease of systole and diastole blood pressure after tomato juice. Based on the results of this research, It can concluded that drinking tomato juice daily can decrease of blood pressure significantly in patients with hypertension.
\end{abstract}

\section{PENDAHULUAN}

Hipertensi merupakan salah satu Penyakit Tidak Menular (PTM) yang menjadi masalah kesehatan yang sangat serius baik di dunia maupun di Indonesia. Peningkatan tekanan darah merupakan salah satu tanda gejala dari hipertensi atau sering disebut juga dengan silent killer atau pembunuh diam-diam, karena salah satu dari tanda gejala dari hipertensi yang tidak nampak pada penderita (Anggraini, 2009).

Menurut data Sample Registration System (SRS) Indonesia tahun 2014, hipertensi dengan komplikasi $(5,3 \%)$ merupakan penyebab kematian nomor 5 (lima) pada semua umur. Pada tahun 2025 kasus hipertensi di negara berkembang seperti Indonesia diperkirakan mengalami peningkatan sekitar $80 \%$ menjadi 1,15 miliar kasus dari jumlah total 639 juta kasus di tahun 2000 (Kemenkes RI, 2017). Data Riset Kesehatan Dasar (Riskesdas), pravelensi hipertensi secara nasional sebesar $31,7 \%$, sedangkan pravelensi Hipertensi di Provinsi NTB sebesar 32,4\% dan lebih tinggi dari angka nasional. Prevalensi Penyakit Hipertensi Menurut Profil Kesehatan Provinsi Nusa Tenggara Barat terus mengalami peningkatan. tahun 2014 sebanyak 64.582 kasus, tahun 2015 sebanyak 121.017 dan tahun 2016 sebanyak 137.836. Berdasarkan data dari Penyakit Tidak Menular (PTM) Dinas Kota Mataram Tahun 2016 populasi keseluruhan penderita hipertensi di puskesmas Karang Pule terdapat sebanyak 678 jiwa sehingga sangat perlu untuk dilakukan http://jurnalilmiah.stikescitradelima.ac.id/index.php/JI Vol.3,No.1, Juli 2019 
penatalaksaan hipertensi untuk menghindari berbagai komplikasi yang berpotensi terjadi seperti serangan jantung atau stroke.

Berdasarkan studi pendahuluan yang dilakukan di puskesmas Karang Pule rata-rata penderta hipertensi mengatakan hanya mengkonsumsi obat anti hipertensi yang diberikan oleh puskesmas, mengurangi asupan garam dan belum pernah mencoba pengoatan alternative lain. Respoden juga mengatakan merasa bosan meminum obat setiap hari.Perubahan pada gaya hidup dan konsumsi obat anti-hipertensi saat ini menjadi salah satu langkah yang efektif untuk menurunkan tekanan darah tinggi. Kewaspadaan hendaknya ditingkatkan pada golongan prehipertensi dengan cara meningkatkan edukasi untuk menurunkan tekanan darah dan mencegahnya terjadi hipertensi dengan cara memodifikasi kebiasaan hidup. Seiring dengan mahalnya biaya pengobatan, masyarakat saat ini mengalihkan pengobatan dan perawatan pada bahan yang bersifat alami. Salah satunya adalah dengan meminum jus tomat.

Tomat kaya akan kalium (235 mg/100gr tomat), sedikit natrium, dan lemak. Kerja kalium dalam menurunkan tekanan darah adalah dapat menyebabkan vasodilatasi, sehingga terjadi penurunan retensi perifer dan meningkatkan curah jantung; kalium berfungsi sebagai diuretika, sehingga pengeluaran natrium dan cairan akan meningkat, kalium menghambat pelepasan renin, sehingga mengubah aktifitas sistem renin angiotensin, kalium dapat mengatur saraf perifer dan sentral yang mempengaruhi tekanan darah (Engelmann et al., 2012). Berdasarkan uraian tersebut, peneliti tertarik melakukan penelitian yang bertujuan untuk mengetahui pengaruh pemberian jus tomat terhadap penurunan tekanan darah pada lansia dengan hipertensi.

\section{METODE PENELITIAN}

Penelitian ini menggunakan rancangan penelitian Pre-Eksperimen dengan menggunakan pendekatan One Group Pre - Post Test without control Design (pra dan pasca tes dalam satu kelompok). Jumlah sampel dalam penelitan ini 16 orang yang diambil dengan menggunakan tekhnik purposive sampling. penelitian ini dilakukan di wilayah kerja puskesmas Karang Pule Kota Mataram. waktu penelitian dilakukan pada bulan April-Mei 2018. prinsip etik yang harus diperhatikan dalam penelitian ini meliputi persetujuan (informed consent), kerahasiaan (Confidentiality), keadilan (justice) dan manfaat (beneficience) (Setiadi, 2007).

Data yang dikumpulkan terdiri dari karakteristik responden, tekanan darah sebelum dan sesudah intervensi. Instrumen pada penelitian ini menggunakan kuesioner yang berisi karakteristik responden, lembar observasi pemberian jus tomat, Sphygmomanometer dan stetoskop. Instrumen penelitian berupa sphygmomanometer dan stetoskop dilakukan uji validasi dengan melakukan kalibrasi alat sebelum digunakan dalam proses pengumpulan data. Pengumpulan data dilakukan dengan terlebih dahulu mengidentifikasi responden berdasarkan kriteria inklusi yang telah ditetapkan dan melakukan informed consent. Selanjutnya peneliti melakukan pengukuran tekanan darah pre intervensi, memberikan jus tomat selama 7 hari dan melakukan pengkuran tekanan darah post intervensi, Analisa data dilakukan melalui dua tahap yaitu analisis univariat dan analisa bivariat. Analisis bivariat menggunakan Uji Wilcoxon dengan $\alpha(0,05)$ dimana sebelumnya telah dilakukan uji normalitas data dengan uji Shapiro Wilk didapatkan hasil data tidak berdistribusi normal $(\alpha 0,252)$.

\section{HASIL PENELITIAN}

\section{a. Hasil Analisis Karakteristik Subyek Penelitian}

Tabel 1. Distribusi Frekuensi Responden yang menderita hipertensi berdasarkan Usia dan Jenis Kelamin, di Wilayah Kerja Puskesmas Karang Pule Kota Mataram

\begin{tabular}{lcc}
\hline \multicolumn{1}{c}{ Variabel } & $\mathrm{n}$ & Presentase \\
\hline Jenis kelamin & & \\
a. Laki-laki & 2 & 12,5 \\
b. Perempuan & 14 & 87,5 \\
Usia & & \\
a. $45-60$ & 6 & 37.5 \\
b. $61-75$ & 8 & 50.0 \\
c. $76-90$ & 2 & 12.5 \\
\hline Jumlah & 16 & 100 \\
\hline
\end{tabular}

Pada tabel 1 diatas terlihat bahwa responden dengan jenis kelamin perempuan $87,5 \%$ dan laki-laki $12,5 \%$, sedangkan usia tertinggi pada

http://jurnalilmiah.stikescitradelima.ac.id/index.php/JI Vol.3,No.1, Juli 2019 


\begin{tabular}{|c|c|c|c|c|c|}
\hline \multicolumn{3}{|c|}{ Tekanan Darah } & $\mathrm{N}$ & $\begin{array}{l}\text { Mean } \\
\text { Rank }\end{array}$ & $\begin{array}{l}\text { Sum } \\
\text { of } \\
\text { Ranks }\end{array}$ \\
\hline \multirow{4}{*}{$\begin{array}{l}\text { pre test - } \\
\text { post test } \\
\text { sistole }\end{array}$} & $\begin{array}{l}\text { Negative } \\
\text { Ranks } \\
\end{array}$ & & $13^{\mathrm{a}}$ & 7.00 & 91.00 \\
\hline & Positive & Ranks & $0^{\mathrm{b}}$ & .00 & .00 \\
\hline & Ties & & $3^{\mathrm{c}}$ & & \\
\hline & Total & & 16 & & \\
\hline \multirow{4}{*}{$\begin{array}{l}\text { pre test - } \\
\text { post test } \\
\text { diastole }\end{array}$} & $\begin{array}{l}\text { Negative } \\
\text { Ranks }\end{array}$ & & $13^{\mathrm{a}}$ & 7.00 & 91.00 \\
\hline & Positive & Ranks & $0^{\mathrm{b}}$ & .00 & .00 \\
\hline & Ties & & $3^{\mathrm{c}}$ & & \\
\hline & Total & & 16 & & \\
\hline \multicolumn{6}{|c|}{$\begin{array}{l}\text { rentang } 61-75 \text { tahun sebanyak } 50,0 \% \text { dan } \\
\text { terendah } 76-90 \text { tahun } 12,5 \% \text {. } \\
\text { b. Hasil Analisis Variabel } \\
\text { Tabel 2. Identifikasi Rata-rata Tekanan Darah } \\
\text { Sebelum dan setelah Pemberian Jus Tomat }\end{array}$} \\
\hline \multirow{2}{*}{$\begin{array}{c}\text { Tekanan } \\
\text { Darah }\end{array}$} & \multicolumn{5}{|c|}{ Sebelum (Pre-Test) } \\
\hline & Min & $\operatorname{Max}$ & Mean & De & $\begin{array}{l}\text { Std. } \\
\text { eviation }\end{array}$ \\
\hline Sistole & 140 & 170 & 151.88 & & 11.087 \\
\hline \multirow[t]{3}{*}{ Diastole } & 90 & 120 & 95.94 & & 8.004 \\
\hline & \multicolumn{5}{|c|}{ Sesudah (Post-Test) } \\
\hline & Min & $\operatorname{Max}$ & Mean & De & $\begin{array}{l}\text { Std. } \\
\text { eviation }\end{array}$ \\
\hline Sistole & 120 & 150 & 130.00 & & 10.954 \\
\hline Diastole & 80 & 100 & 88.75 & & 7.188 \\
\hline
\end{tabular}

c. Hasil Analisis Bivariate

Tabel 3. Analisa Pengaruh Tekanan Darah Sebelum dan Setelah Pemberian Jus Tomat Terhadap Penurunan Tekanan Darah pada Lansia dengan Hipertensi Di Wilayah Kerja Puskesmas Karang Pule Tahun 2018

Berdasarkan tabel 3 diatas menunjukkan bahwa pada tekanan darah darah kategori sistole dan diastole terdapat masing-masing 13 responden yang mengalami penurunan tekanan darah setelah pemberian jus tomat, sedangkan terdapat masing-masing 3 responden yang tidak mengalami penurunan tekanan darah setelah pemberian jus tomat dari total keseluruhan 16 responden.

Tabel 4: Analisa Tekanan Darah Sebelum dan Setelah Pemberian Jus Tomat Terhadap Penurunan Tekanan Darah pada Lansia dengan Hipertensi Di Wilayah Kerja Puskesmas Karanag Pule Tahun 2018

\begin{tabular}{llcc}
\hline & \multicolumn{2}{c}{$95 \%$ Confidence } & \\
\cline { 2 - 3 } Tekanan Darah & $\begin{array}{c}P \text { Interval } \\
\text { Lower }\end{array}$ & Upper & Value \\
& Bound & Bound & \\
\cline { 3 - 4 } & 0.000 & 0.000 & 0.000 \\
\cline { 1 - 1 } Pre Test Sistolie & & & 0.000 \\
\hline Post Test Sistolie & Pre Test Diastole & & 0.000 \\
\hline Post Test Diastole & & &
\end{tabular}

Berdasarkan tabel 2 di atas dapat diketahui bahwa tekanan darah sistole sebelum pemberian jus tomat diperoleh nilai minimum $140 \mathrm{mmHg}$ dan nilai maximum $170 \mathrm{mmHg}$ dan mean skor $151.88 \mathrm{mmHg}$ dengan nilai standar deviation 11.087 dan diastole sebelum pemberian jus tomat diperoleh nilai minimum $90 \mathrm{mmHg}$ dan nilai maximum $120 \mathrm{mmHg}$ dan mean skor $95.94 \mathrm{mmHg}$ dengan nila standar deviation 8.004. Sedangkan tekanan darah sistole setelah pemberian jus tomat diperoleh nilai minimum $120 \mathrm{mmHg}$ dan nilai maximum $150 \mathrm{mmHg}$ dan mean skor $130.00 \mathrm{mmHg}$ dengan nilai standar deviation 10.954 dan diastole sebelum pemberian jus tomat diperoleh nilai minimum $80 \mathrm{mmHg}$ dan nilai maximum $100 \mathrm{mmHg}$ dan mean skor 88.75 mmHg dengan nila standar deviation 7.188
Berdasarkan tabel 4 di atas menunjukkan hasil uji Wilcoxon tekanan darah dengan hasil statistik signifikan $\mathrm{p}=0,000(\mathrm{p}<0,05)$, artinya hasil analisis menunjukkan bahwa adanya setelah pemberian jus tomat terhadap lansia dengan hipertensi

\section{PEMBAHASAN}

Berdasarkan hasil penelitian, dapat diketahui bahwa hasil rata-rata tekanan darah sebelum dan sesudah pemberian jus tomat menunjukkan ratarata penurunan nilai skor tekanan darah sistole dari 151.88 sebelum perlakuan menjadi 130.00 setelah perlakuan dan rata-rata penuruan nilai skor tekanan darah diastole dari 95.94 sebelum perlakuan menjadi 88.75 setelah perlakuan. sedangkan hasil analisa uji Wilcoxon

http://jurnalilmiah.stikescitradelima.ac.id/index.php/JI Vol.3,No.1, Juli 2019 perubahan tekanan darah sistole dan diastole 
menunjukkan penurunan tekanan darah dengan hasil statistik signifikan $p=0,000(p<0,05)$, artinya hasil analisis menunjukkan bahwa adanya penurunan tekanan darah sistole dan diastole sesudah pemberian jus tomat.

Hasil penelitian ini sejalan dengn peneltian yang dilakukan oleh Lestari dan Rahayuningsih (2017) menyimpulkan bahwa pemberian jus tomat selama 7 hari berturut-turut dapat menurunkan tekanan darah sistole dan diastole secara signifikan pada wanita postmenopause hipertensi.

Adanya penurunan tekanan darah sesudah pemberian jus tomat karena kerja kalium dalam menurunkan tekanan darah dapat menyebabkan vasodilatasi, sehingga terjadi penurunan retensi perifer dan meningkatkan curah jantung (Engelhard et al, 2006; Gunawan dkk, 2016; Grace \& Aryu, 2016). Suplemen kalium dalam tomat dan lycopene, dapat berguna pada terapi hipertensi. Tomat mengandung antioksidan kuat yang menghambat penyerapan oksigen reaktif terhadap endotel yang mengganggu pelebaran pembuluh darah, sehingga menyebabkan hipertensi, ini yang menjadi salah satu patofisiologi mengapa tomat dapat menurunkan tekanan darah (Javob, 2005 dalam penelitian Raharjo 2007).

Berdasarkan hasil observasi penelitian, terjadi perubahan kualitas tidur dengan tekanan darah dalam penelitian ini sebagian besar disebabkan oleh jus tomat yang dilakukan oleh responden karena selama proses penelitian adanya pemberian jus tomat dan selama proses penelitian terjadinya perubahan tekanan darah secara bertahap dari hari pertama sampai hari ke tujuh, hal ini didukung dengan hasil pengukuran tekanan darah responden bahwa setiap responden mengalami penurunan tekanan darah. Berdasarkan hasil penelitian tersebut, terdapat kesesuaian teori bahwa kalium dalam jus tomat dapat menurunkan tekanan darah dengan menghambat pelepasan renin sehingga terjadi peningkatan ekskresi natrium dan air (Nuziyati dkk, 2016; Haddy et al., 2006; Jacob, 2006). Renin beredar dalam darah dan bekerja dengan mengkatalisis penguraian angiotensin menjadi angiotensin $I$. angiotensin I berubah untuk aktifnya yaitu angiotensin II dengan bantuan Angiotensin Converting Enzyme (ACE). Angiotensin II berpotensi besar meningkatkan tekanan darah karena bersifat sebagai vasikontriksi dan dapat merangsang pengeluaran aldosteron. Aldosteron meningkatkan tekanan darah dengan jalan retensi natrium. Retensi natrium dan air menjadi berkurang dengan adanya kalium, sehingga terjadi penurunan volume plasma, curah jantung, tekanan perifer, dan tekanan darah (Lestari \& Rahayuningsih, 2017).

\section{SIMPULAN}

Tekanan darah pada lansia dengan hipertensi sebelum diberikan jus tomat dengan rata-rata tekanan darah sistole $151.88 \mathrm{mmHg}$ dan diastole rata-rata tekanan darah $95.94 \mathrm{mmHg}$ dan setelah diberikan jus tomat dengan rata-rata tekanan sistole $130.00 \mathrm{mmHg}$ dan rata-rata tekanan diastole $88.27 \mathrm{mmHg}$. Hasil uji menunjukkan bahwa adanya pengaruh yang signifikan terhadap pemberian jus tomat pada penurunan tekanan darah lansia yang mengalami hipertensi dengan nilai $\rho=0,000 \quad(\rho<0.05)$. Penelitian ini dapat dijadikan sebagai obat alternatif nonfarmakologi dalam penangangan hipertensi selain menggunakan obat farmalakologi bahwa dengan mengonsumsi jus tomat setiap hari dapat menurunkan tekanan darah pada penderita hipertensi

\section{DAFTAR PUSTAKA}

Anggraini, dkk. (2009). Faktor-Faktor Yang Berhubungan Dengan Hiperteni Pada Kelompok Lansia. [diakses tanggal 12 Desember 2017].

Engelhard, YN, Gazer B, MD, Paran E. (2006). Natural antioxidants from tomato extract reduce blood pressure in patients with grade-1 hypertension: A double-blind, placebo-contolled pilot study. Am heart J 151:100.e1- $100 . \quad$ e6. http://www.ncbi.nih.gov/pubmed/16368299. [diakses tanggal 13 Desember 2017] (dalam penelitian Nada Ismalia 2016).

Engelmann NJ, Clinton SK, Erdman-Jr JW. (2012). Nutritional aspect of phytoene and phytofluene, carotenoid precussors to lycopene. Adv Nutr: 2(1):51-61. [diakses tanggal 13 Desember 2017] (dalam penelitian Nada Ismalia 2016).

http://jurnalilmiah.stikescitradelima.ac.id/index.php/JI Vol.3,No.1, Juli 2019 
Gunawan I. Z, Dkk. (2016). Pemberian Jus Belimbing Dan Jus Tomat Terhadap Perubahan Tekanan Darah Sistolik dan Diastolik pada Penderita Hipertensi di Puskesmas Taragog Dan RS Al Islam Bandung. Bandung: Asosiasi Dietisien Indonesia. Hal 405-11.

Grace S. A. \& Aryu C. (2016). Perbubahan Penurunan Tekanan Darah Sistolik Dan Lanjut Usia Hipertensi Yang Diberi Jus Tomat (Lycopene Commune) Dengan Kulit Dan Tanpa Kulit. Vol. 3 No.1 (158-162).

Haddy FJ, Vanhoutte PM, Feleton M. (2006). Role of potassium in regulating blood flow and blood pressure. Am J physiol Regul Integr Comp Physiol. 290:546552. [diakses tanggal 13 Desember 2017] (dalam penenlitian Nada Ismalia 2016).

Jacob, G. (2006). Hypertension (High Blood Pressure): Foot/Diet Therapy for Hypertension dalam www.hlisticonline.com/Remedies/Heart l-hypert_diet_theraphy.ht.m. [diakses tanggal 13 Desember 2017] (dalam penelitian Priyo Raharjo 2007).

Kemenkes RI. (2017). Profil Kesehatan Indonesia tahun 2017. Kemenkes RI: Jakarta.

Lestari, D. \& Rahayuningsih. (2017). Hubungan Asupan Kalium, Kalsium, Magnesium, dan Natrium, Indeks Masa Tubh, Serta Aktivitas Fisik dengan Kejadian Hipertensi pada Wanita Usia 30-40 Tahun. Artikel Penelitian Universitas Diponegoro: Vol. 3. No. 2: 85-90.

Nuziyati dkk. (2016). Pengaruh Pemberian Jus Tomat Terhadap Penurunan Tekanan Darah Sistolik dan Diastolik Penderita Hipertensi dada Lansia di Wilayah Kerja Puskesmas Kulisusu
Kabupaten Buton Utara Tahun 2016. Vol. 5. No. 10: 188-190.

Profil Dinkes NTB. (2016). Prevalensi Penyakit Hipertensi. [diakses 11 Januari 2018].

Setiadi. (2007). Konsep \& Penulisan Riset Keperawatan. Yogyakarta: Graha Ilmu

Word Health Organization. (2012). A Global Brief on Hypertension. Silent Killer, global Public Health Crisis. Ganeva: WHO Press. 